\title{
Corn Response to an Integrated Plant Nutrition System (IPNS) With Humic Acid and Biofertilizers
}

\author{
Jose F. Da Cunha Leme Filho ${ }^{1}$, Wade E. Thomason ${ }^{1}$, Gregory K. Evanylo ${ }^{1}$, Xunzhong Zhang ${ }^{1}$, \\ Michael S. Strickland ${ }^{2}$, Bee K. Chim ${ }^{3}$, Cameron Bermand ${ }^{1} \&$ Andre Diatta $^{1}$ \\ ${ }^{1}$ School of Plant \& Environmental Sciences, Virginia Polytechnic Institute \& State University, Blacksburg, VA, \\ USA \\ ${ }^{2}$ Department of Soil and Water Systems, University of Idaho, Moscow, ID, USA \\ ${ }^{3}$ North Central Agriculture Research Lab, United States Department of Agriculture-Agricultural Research \\ Service, Brookings, SD, USA \\ Correspondence: Jose F. Da Cunha Leme Filho, School of Plant \& Environmental Sciences, Virginia Polytechnic \\ Institute \& State University, 330 Smyth Hall, 185 Ag Quad Lane, Blacksburg, VA 24061, USA. Tel: \\ 1-334-750-9970. E-mail: jfleme@vt.edu
}

\author{
Received: May 25, $2020 \quad$ Accepted: June 29, $2020 \quad$ Online Published: July 15, 2020 \\ doi:10.5539/jas.v12n8p25 URL: https://doi.org/10.5539/jas.v12n8p25
}

\begin{abstract}
Sustainable agriculture production depends on the development of methods that optimize nutrient cycling, minimize use of external inputs, and maximize input use efficiency according to the conditions of each region. The principle of an integrated plant nutrition system (IPNS) is to tailor plant nutrition and soil fertility management, taking advantage of the combined and harmonious use of inorganic, organic and biological resources. This greenhouse study investigated the individual and combined use of inorganic, organic and biological fertilizer resources for corn (Zea mays L.). We evaluated the effects of commercial synthetic fertilizer, humic acid products, compost/manure teas and bioinoculant as inorganic, organic and biological resources, respectively, and their synergy on corn growth and soil respiration parameters under a period of water stress. The pots were laid out in completely randomized design and the total of sixteen treatment combinations were replicated four times. In general, when comparing to the control values, the use of humic acid (HA), biofertilizers and the integration of both compounds generated significantly greater early season plant height, chlorophyll content, photosynthetic efficiency and shoot/root dry biomass. The soil substrate induced respiration was affected by only one biofertilizer product at two different rates. Though all pots received adequate synthetic fertilizer, the control plants were generally smaller and less vigorous compared to the plants receiving either HA or biofertilizer treatments, but no additive benefit was observed for the integrated practice compared to individual applications. Further studies addressing different types and levels of stress along with greater stress duration should be conducted to validate these findings.
\end{abstract}

Keywords: bioinoculants, compost tea, manure tea, organic fertilizer, humates, water stress, plant biostimulants

\section{Introduction}

Successful crop production relies on nutrients that are available in sufficient quantities and forms to promote satisfactory plant growth. Fertilization is an essential practice to enhance soil fertility, increase crop productivity and support agricultural intensification (Vaneeckhaute et al., 2013). Optimized fertilization schemes require methods to optimize nutrient cycling, minimize use of external inputs, and maximize input use efficiency appropriate to the conditions of each region (Cakmak, 2002; Kumwenda, Waddington, Snapp, Jones, \& Blackie, 1996).

A huge variety of materials can serve as sources of plant nutrients. These can be inorganic, organic, recycled wastes or a range of biological products including compost teas and microbial inoculants. The nature and the characteristics of nutrient release from fertilizers derived from inorganic, organic and biological resources differ and thus must be managed differently (Chen, 2006; Dutta, Pal, Chakraborty, \& Chakrabarti, 2003). Sustaining high crop yields should include not only the addition of synthetic fertilizer materials but also the integrated use of biological and organic nutrient resources as a way to increase nutrient use and minimize environmental 
impacts (Hussain, Jilani, \& Iqbal, 1988; Kaur, Kapoor, \& Gupta, 2005). According to the Food and Agriculture Organization of the United Nations (FAO) (Shand, 2007), the definition of an IPNS is "the adaptation of the plant nutrition and soil fertility management in farming systems to site characteristics, taking advantage of the combined and harmonious use of inorganic, organic and biological nutrient resources to serve the concurrent needs of food production and economic, environmental and social viability." The principle of IPNS requires an understanding of nutrient dynamics throughout the soil-microbe-plant systems in order to regulate the availability of nutrients derived from inorganic, organic and biological sources to address long- and short-term crop production and environmental impacts (Aulakh \& Grant, 2008).

Several studies addressing different crop species have shown the beneficial effects of the integrated use of different fertilizer or biostimulant sources on yield, shoot and root growth, and nutrient uptake on different species (Adesemoye, Torbert, \& Kloepper, 2008; Mantelin \& Touraine, 2004) such as sugarcane (Saccharum officinarum L.) (Bokhtiar \& Sakurai, 2005; Sundara, Natarajan, \& Hari, 2002) and red pepper (Capsicum annuum L.) (Joo, Kim, Lee, Song, \& Rhee, 2004). However, in managed ecosystems, the dynamics of nutrient availability will vary depending on the nutrient resource applied.

The heterogeneous and complex molecules present in humic substances have shown many positive effects on plant growth, nutrient uptake efficiency and soil. Commonly, these effects can be intercorrelated and complementary. Plant growth stimulation from the use of HA has been reported in such ways as increased berry size and improved fruit quality in table grapes [Vitis Vinifera (L.) cv. Italia] (Ferrara \& Brunetti, 2010) and greater root growth on Brazilian red cloak (Megaskepasma erythrochlamys) and sanchezia (Sanchezia nobilis L.) (Baldotto \& Baldotto, 2014) and tobacco (Nicotiana tabacum L.) (Mylonas \& McCants, 1980). Humic compounds stimulate plant development through improving nutrient adsorption on lily (Lilium L.) (Chang, Wu, Xu, Nikbakht, \& Xia, 2012) and gerbera (Gerbera jamesonii L.) (Nikbakht et al., 2008). Furthermore, humic acids can promote vegetal growth by mediating biochemical, morphological, physiological processes (Chen, Senesi, \& Schnitzer, 1977; Tahiri, Destain, Thonart, \& Druart, 2015; Vaughan \& Malcolm, 1985).

The application of HA can positively affect soil cation exchange capacity and nutrient availability which indicates that HA materials may serve as resources that can improve fertilization efficiency (Albiach, Canet, Pomares, \& Ingelmo, 2001; Tahiri et al., 2015; Vaughan \& MacDonald, 1976). Thus, the physicochemical activity and structure of HA substances might increase agriculture production through improved soil quality and by enhancing soil stability and resistance to erosion (Brannon \& Sommers, 1985; Spaccini, Piccolo, Conte, Haberhauer, \& Gerzabek, 2002). The dual beneficial effects of HA on soil and plant might explain the production increase on tomato (Solanum lycopersicum L.), cotton (Gossypium arboretum L.) and grapes (Vitis vinifera L.) (Brownell, Nordstrom, Marihart, \& Jorgensen, 1987) as improved soil promotes better conditions for plant growth.

Several studies have documented enhancement of vegetative growth, yield and nutrient uptake by improving the physico-chemical properties of the soil (Kim et al., 2015; Siddiqui, Islam, Naidu, \& Meon, 2011) and incremental benefits to the microbial population for plants and soil fertility (Chen, 2015) in response to compost tea (CT) application. Moreover, solubilization of $\mathrm{P}$ or K, uptake of $\mathrm{N}$ and multiplication of extraradical hyphae biomass are effects promoted by biofertilizers that might minimize negative impacts of soil degradation, in addition to induction of plant growth (Bianciotto \& Bonfante, 2002; Rodríguez \& Fraga, 1999). Therefore, the application of microbial inoculants has shown the potential to improve sustainable production in intensive agriculture systems (Bhattacharyya \& Jha, 2012; Chauhan, Bagyaraj, Selvakumar, \& Sundaram, 2015) due to nutrient release, plant growth stimulation, rhizoremediation and plant stress control (Lugtenberg \& Kamilova, 2009).

In fact, the potential benefits of HA and biofertilizers as plant-growth promoters for increased nutrient acquisition (Yildirim, 2007), increased stress tolerance (Zhang \& Ervin, 2004), and pathogen suppression (On et al., 2015) are evident in the literature, and substantial work has been done in this area. Thus, plant-microbial symbioses are very important components of nutrient cycling in agroecosystems and enhance plant nutrient uptake (Peoples \& Craswell, 1992; Zhu, Cavagnaro, Smith, \& Dickson, 2001). Studies have shown that HA stimulates microbial effects on ion exchange and metal complexing (chelating) systems (Puglisi et al., 2009; Visser, 1985). Also, HA has increased the production of micelium by mycorrhizal fungi (Gryndler et al., 2005) and promoted greater nodule formation of native rhizobia (Gaur \& Bhardwaj, 1971).

Despite the recognition of the independent effects of HA and biofertilizers, few applicable studies have been conducted to elucidate the interaction of HA and biofertilizers on agronomic, economic and/or environmental outcomes. Moreover, there is a lack of knowledge regarding the effects of HA on plant-microbial symbioses. 
Therefore, the present study evaluated the effects of the combined and individual use of HA and compost/manure teas and bioinoculants along with inorganic fertilizer on corn (Zea mays L.) development and soil respiration. We hypothesize that the synergetic effects of the combination of HA + biofertilizer will improve corn agronomic outcomes and increase soil respiration when comparing the application of each product alone.

\section{Materials and Methods}

In this greenhouse study, humic acid (HA) was used as an organic resource and compost/manure tea and bioinoculants were used as biological resources along with conventional inorganic fertilizer resources (NPK) in an integrated manner.

\subsection{Products Description (Treatments)}

Seven products, including inorganic, organic and biological resources, were used in this study. The inorganic fertilizer was Osmocote Plus ${ }^{\circledR}$; the organic product was MicroLife Humic Acid Complex ${ }^{\circledR}$; and the biological products were SoilSoup ${ }^{\circledR}$, Microgeo ${ }^{\circledR}$ and Microgro Supreme Bioinoculant ${ }^{\circledR}$. The MicroLife $6-2-4^{\circledR}$ and Nanobind ${ }^{\circledR}$ are derived from organic and biological resources. The Osmocote Plus ${ }^{\circledR}$ is a slow release synthetic fertilizer containing 11 essential nutrients for plants. The organic/ humic category was represented by MicroLife Humic Acid Complex ${ }^{\circledR}$ which was constituted of $15 \%$ humic acid and $1 \%$ fulvic acid. One of the three biological fertilizers was Microgeo ${ }^{\circledR}$, which is a Brazilian patented product categorized as a manure tea. This biofertilizer is composed of organic compounds, active and dormant cells from various microorganisms (bacteria, yeasts, filamentous fungi, and algae), metabolites and organo-mineral chelates and it is produced through continuous anaerobic fermentation in a liquid media (D'Andrea, 2002). According to the technical manual, the preparation is using the $\mathrm{CLC}^{\circledR}$ (Continuous Liquid Composting) process, where $5 \%$ of the commercial biological fertilizer Microgeo ${ }^{\circledR}, 15 \%$ of ruminal content and water are mixed in a tank exposed to sunlight. After 15 days the biofertilizer is ready to be applied. SoilSoup ${ }^{\circledR}$ is an aerobic compost tea generated via fermentation of vermicompost over 24 hours with the addition of nutrient solution (molasses, bat guano, sea bird guano, soluble kelp, langbeinite, natural citric acid, ancient seabed minerals, yucca) and oxygen to the system (aquarium pump). The Microgro Supreme Bioinoculant ${ }^{\circledR}$ is a water-soluble powder containing 76 different strains of bacteria and fungi including 11 different Mycorrhizal species and microbial food (sugars, humic acid, kelp, amino acids and yeast extract). The MicroLife $6-2-4^{\circledR}$ is a pelletized fertilizer that contains 6,2 and $4 \% \mathrm{~N}, \mathrm{P}$ and $\mathrm{K}$, respectively. These nutrients are derived from a combination of organic and biological materials including fish, kelp, molasses, humates, bat guano, rock phosphate, wheat middlings, soy meal, cottonseed meal, alfalfa, corn meal, potassium sulfate, iron sulfate, Folic Acid, vitamins and bioinoculants. Nanobind ${ }^{\circledR}$ is constituted by the combination of humic substances and microbial inoculants. The products' descriptions are summarized in Table 1.

Table 1. Product description

\begin{tabular}{|c|c|c|c|c|}
\hline Resource & Category & Subcategory & Name & Components \\
\hline Inorganic & Synthetic & & Osmocote Plus & $\begin{array}{l}\text { Polymer-coated: Ammonium Nitrate, Ammonium Phosphate, Potassium Sulfate, } \\
\text { Magnesium Sulfate, Sodium Borate, Iron Phosphate, Iron EOTA, Manganese } \\
\text { Sulfate, Sodium Molybdate, Aibc Sulfate, Copper Sulfate and Zinc Oxide. }\end{array}$ \\
\hline Organic & Humic & Fulvic & $\begin{array}{l}\text { Microlife Humic } \\
\text { Acid Complex }\end{array}$ & 15\% Humic Acid and 1\% Fulvic Acid derived from leonardite \\
\hline \multirow{5}{*}{ 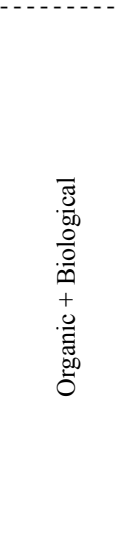 } & \multirow{5}{*}{ : } & Manure tea & Microgeo & $\begin{array}{l}\text { Recancitran Substances, Biodynamic Preparations, Pentoses, Minerals and Brans } \\
\text { and the microorganisms produced in the manure tea fermentation }\end{array}$ \\
\hline & & Compost tea & SoilSoup & $\begin{array}{l}\text { Molasses, Bat Guano, Sea Bird Guano, Soluble Kelp, Langbeinite, Natural Citric } \\
\text { Acid, Ancient Seabed Minerals, Yucca and the microorganisms produced in the } \\
\text { compost tea fermentation }\end{array}$ \\
\hline & & \multirow{3}{*}{ 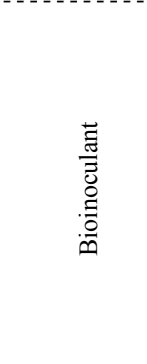 } & $\begin{array}{l}\text { Microgro Supreme } \\
\text { Bioinoculant }\end{array}$ & $\begin{array}{l}76 \text { different strains of bacterias and fungi planced on dry milk carrier loaded with } \\
\text { microbial food. The microorganisms included are: species of Genus Bacillus, } \\
\text { Psuedomonas,Streptomycetes, Trichoderma, and Endo and Ectomycorrhizal Fungi }\end{array}$ \\
\hline & & & Microlife 6-2-4 & $\begin{array}{l}\text { Fish, Kelp, Molasses, Emery Humates, Bat Guano, Rock Phosphate, Wheat } \\
\text { Middling's, Soy Meal, Cottonseed Meal,Alfalfa, Corn Meal, Potassium Sulfate, } \\
\text { Iron Sulfate, Amino Acids, Folic Acid,Vitamins and MicroGro Supreme } \\
\text { BioInoculant }\end{array}$ \\
\hline & & & Nanobind & $\begin{array}{l}\text { Lactobacillus culture, Saccharomyces Boulardii culture, Phytase enzymes, Lipase } \\
\text { enzymes, Amylase enzymes, Superoxide Dismutase enzymes, Protease enzymes, } \\
\text { organic carbon (humic) }\end{array}$ \\
\hline
\end{tabular}




\subsection{Experimental Design and Management}

The experiment was conducted under controlled conditions in a greenhouse in Blacksburg (Virginia, USA) to investigate the individual and combined effects of humic acid (HA), compost/manure tea and bioinoculants on corn growth. Polyethylene pots (19 cm tall, $19 \mathrm{~cm}$ outside diameter, and $37851 \mathrm{~cm}^{3}$ volume) were lined with plastic bags to avoid water loss. Soil media and sand (50\% Metro-mix 360 and 50\% playground sand, respectively) were placed in a polyethylene pot and $21 \mathrm{~g}$ of inorganic fertilizer (Osmocote Plus $®$ ) was equally added in each pot. According to the bulk density provided in the physical/chemical characteristics data sheet of each component, we added $0.425 \mathrm{~kg}$ Metro-mix 360 and $3 \mathrm{~kg}$ sand to each pot to have an equal volume. Posteriorly, corn seeds were planted by hand at $3 \mathrm{~cm}$ depth and thinned to one seedling after germination.

The field capacity on the soil media + sand was determined after water saturation until the first drop of water leached through the bottom of the pot. Then, after 1 day the weight of the pot containing the wet soil was taken to be used as field capacity threshold (Kirkham, 2014).

We employed 6 treatments, each at two concentration levels, $1 \mathrm{x}$ and $2 \mathrm{x}$ the label rate of each product, depending on the treatment (Table 2). The trial used a completely randomized design (CRD) with four replications. Each treatment was applied at corn growth stages V1, V4, V6 and V8. The treatments were previously prepared in the laboratory and applied into each pot using an electronic pipette. Solid materials were dissolved in water and the appropriate rate applied to respective pots.

Table 2. Treatments and application rate

\begin{tabular}{|c|c|c|c|c|}
\hline \multirow{2}{*}{ No. } & \multicolumn{4}{|c|}{ Treatments } \\
\hline & Product Name and Abbreviation & Rate & Label & Rate/pot (each application) \\
\hline 1. & Microgeo (M) & $1 \mathrm{x}$ & 150 1/ha & $0.47 \mathrm{ml}$ \\
\hline 2. & Microgeo (M) & $2 \mathrm{x}$ & 150 1/ha & $0.94 \mathrm{ml}$ \\
\hline 3. & Soil Soup (S) & $1 \mathrm{x}$ & 235 1/ha & $0.73 \mathrm{ml}$ \\
\hline 4. & Soil Soup (S) & $2 \mathrm{x}$ & $2351 / \mathrm{ha}$ & $1.46 \mathrm{ml}$ \\
\hline 5. & Microgro Supreme Bio inoculant (MB) & $1 \mathrm{x}$ & $6.1 \mathrm{~kg} / \mathrm{ha}$ & $19 \mathrm{mg}$ \\
\hline 6. & Microgro Supreme Bio inoculant (MB) & $2 \mathrm{x}$ & $6.1 \mathrm{~kg} / \mathrm{ha}$ & $38 \mathrm{mg}$ \\
\hline 7. & Microlife Humic (H) & $1 \mathrm{x}$ & $14 \mathrm{l} / \mathrm{ha}$ & $0.043 \mathrm{ml}$ \\
\hline 8. & Microlife Humic (H) & $2 \mathrm{x}$ & 14 1/ha & $0.086 \mathrm{ml}$ \\
\hline 9. & Nanobind $(\mathrm{N})$ & $1 \mathrm{x}$ & $4.61 / \mathrm{ha}$ & $0.015 \mathrm{ml}$ \\
\hline 10. & Nanobind $(\mathrm{N})$ & $2 \mathrm{x}$ & $4.6 \mathrm{l} / \mathrm{ha}$ & $0.030 \mathrm{ml}$ \\
\hline 11. & Microlife 6-2-4(ML) & $1 \mathrm{x}$ & $975 \mathrm{~kg} / \mathrm{ha}$ & $3000 \mathrm{mg}$ \\
\hline 12. & Microlife 6-2-4(ML) & $2 \mathrm{x}$ & $975 \mathrm{~kg} / \mathrm{ha}$ & $6000 \mathrm{mg}$ \\
\hline 13. & Microgeo + Microlife Humic $(M+H)$ & $1 \mathrm{x}, 1 \mathrm{x}$ & 150 1/ha and 14 1/ha & $0.47 \mathrm{ml}+0.043 \mathrm{ml}$ \\
\hline 14. & Soil Soup + Microlife Humic $(\mathrm{S}+\mathrm{H})$ & $1 \mathrm{x}, 1 \mathrm{x}$ & 235 1/ha and 14 1/ha & $0.73 \mathrm{ml}+0.043 \mathrm{ml}$ \\
\hline 15. & Microgro Supreme Bio inoculant + Microlife Humic $(\mathrm{MB}+\mathrm{H})$ & $1 \mathrm{x}, 1 \mathrm{x}$ & $6.1 \mathrm{~kg} / \mathrm{ha}$ and $14 \mathrm{l} / \mathrm{ha}$ & $19 \mathrm{mg}+0.043 \mathrm{ml}$ \\
\hline 16. & Control (C) & $0 \mathrm{x}$ & 0 & 0 \\
\hline
\end{tabular}

Note. The surface area on top of the pot was $314 \mathrm{~cm}^{2}$.

\subsection{Water Regime and Data Collection}

The pots were maintained at $60 \%$ of field capacity for the first 40 days of the experiment to ensure adequate moisture for corn growth. Between 40 and 50 days post-emergence (PE), watering was reduced to $30 \%$ of field capacity to induce mild to moderate drought stress. Plant height at the leaves within the whorl, atLEAF chlorophyll meter value (FT Green LLC, Wilmington, DE) and photosynthetic efficiency/OS-50II fluorometer (Opti-Sciences, Tyngsboro, MA) measurements were collected from the latest fully developed leaf defined using the leaf collar method (Abendroth, Elmore, Boyer, \& Marlay, 2011) at 20, 40 and 60 days PE. At 60 days post-emergence, the aboveground plant material was clipped at the soil surface and dried at $70{ }^{\circ} \mathrm{C}$ until a constant weight was achieved so that plant dry matter yield could be calculated. Corn growth stages corresponding to 20, 40 and 60 days post-emergence were V4, V6 and V8, respectively. After aboveground biomass harvest, roots were separated from the soil media + sand by shaking and root dry matter calculated in a similar manner to the shoot. 


\subsection{Substrate-Induced Respiration}

A subsample of soil from the whole pot (300 g) was collected at the end of the growth period following aboveground and root biomass collection. Substrate-induced respiration (SIR) was performed to determine active microbial biomass in soil samples (Fierer, Schimel, \& Holden, 2003). The collected samples were weighed (4g dry weight equivalent) into modified $250 \mathrm{ml}$ centrifuge tubes modified with holes drilled in the tube caps and filled with rubber caulk to facilitate gas extraction. Soils were conditioned to an incubation temperature of $20^{\circ} \mathrm{C}$ prior to the addition of substrate. To each sample, $8 \mathrm{ml}$ of yeast substrate was added $\left(12 \mathrm{~g} \mathrm{BD}\right.$ Bacto $^{\mathrm{TM}}$ yeast extract/liter $\mathrm{H}_{2} \mathrm{O}$ ) and the sample was placed on a shaker for 1 hour. After thoroughly mixing substrate and soil, the tubes were tightly sealed and flushed with $\mathrm{CO}_{2}$ free air for 3 minutes. After incubation at $20^{\circ} \mathrm{C}$ for 5 hours, a syringe was used to remove $5 \mathrm{ml}$ of headspace gas from the sealed tubes. Analysis of the sample was performed with a Licor model LI-7000 infrared gas analysis (IRGA) (LI-COR Corporate, Lincoln, NE) to determine $\mathrm{CO}_{2}$ concentration and soil respiration rate (ug $\mathrm{CO}_{2} / \mathrm{g}$ dry soil/hour).

\subsection{Data Analysis}

Analysis of variance using PROC GLM of SAS 9.4 (SAS Institute, 2011) was conducted to evaluate treatment effects on plant height, atLEAF chlorophyll meter values, photosynthetic efficiency and root, shoot and total biomass. Differences between treatments and control means were separated using Dunnett's test and the t-test of the means were deemed significant differences when F-test values were $\alpha<0.05$ for the plant parameters and $\alpha<$ 0.1 for the SIR. Single-degree of freedom contrasts were used to determine significant differences between rates of the same product.

\section{Results and Discussion}

\subsection{Plant Height}

Generally, treatments positively impacted plant height to a greater degree as the study progressed from 20 to 60 days PE (Table 3 ).

Table 3. Analysis of variance of the effects of IPNS treatments on plant height, atLEAF and Fluoremeter at 20, 40 and 60 days post-emergence (PE)

\begin{tabular}{|c|c|c|c|c|c|c|c|c|c|}
\hline \multirow{2}{*}{ Source } & \multicolumn{3}{|c|}{ Plant height } & \multicolumn{3}{|c|}{ atLEAF } & \multicolumn{3}{|c|}{ Fluorometer } \\
\hline & 20 days $\mathrm{PE}$ & 40 days $\mathrm{PE}$ & 60 days $\mathrm{PE}$ & 20 days $\mathrm{PE}$ & 40 days $P E$ & 60 days $\mathrm{PE}$ & 20 days PE & 40 days $\mathrm{PE}$ & 60 days $P E$ \\
\hline & $\operatorname{Pr}>f$ & & & & & & & & \\
\hline Rep & 0.2985 & 0.0047 & $<0.0001$ & 0.1869 & 0.1316 & 0.0095 & $<0.0001$ & 0.0113 & 0.5537 \\
\hline Treatment & 0.044 & 0.0002 & $<0.0001$ & 0.0089 & 0.1715 & 0.0265 & $<0.0001$ & $<0.0001$ & $<0.0001$ \\
\hline $\mathrm{CV}$ & 13.8 & 7.0 & 8.2 & 7.9 & 7.0 & 3.1 & 4.8 & 3.3 & 2.4 \\
\hline SED & 6.1 & 4.2 & 10.3 & 4.5 & 3.8 & 2.0 & 0.034 & 0.026 & 0.019 \\
\hline
\end{tabular}

Progressively, the number of treatments with plant height significantly greater than the control increased as the study progressed. The number of treatments with plants significantly taller than the control increased from 5 to 7 and then 11 at 20, 40 and 60 days PE, respectively (Table 4). Mbagwu and Piccolo (1997) tested the responses of coal-derived humic substances on corn and they also found increases in plant height, even though the plants in their research were generally shorter than this current study when comparing the plant height around 5 weeks after emergence. Several studies have shown the influence of biofertilizers on plant height stimulation of species like potato (Solanum tuberosum L.), tomato, maize (Bhattacharyya \& Jha, 2012), tobacco (Zhang \& Kong, 2014) and wheat (Triticum aestivum L.) (Aftab \& Asghari, 2008). Moreover, a study on compost tea reported a pattern of increased plant height of lettuce (Lactuca sativa L.), soybean (Glycine max L.) and sweet corn as concentration of compost tea increased from $0.1 \%, 0.2 \%, 0.4 \%$, to $0.8 \%$ of the total application (Kim et al., 2015). 
Table 4. Mean height of control plants and differences between height of treatment and control at 20, 40 and 60 days PE

\begin{tabular}{|c|c|c|c|c|c|c|c|}
\hline \multirow{2}{*}{ Category } & \multirow{2}{*}{ Treatment comparison } & \multicolumn{6}{|c|}{ Difference between treatments and control values } \\
\hline & & \multicolumn{2}{|c|}{20 days $\mathrm{PE}$} & \multicolumn{2}{|c|}{40 days $\mathrm{PE}$} & \multicolumn{2}{|c|}{60 days $\mathrm{PE}$} \\
\hline \multirow{7}{*}{ Biofertilizer } & & $-----\cdot$ & $-\cdots$ & -- Plar & heig & ------- & - \\
\hline & $\mathrm{M}-\mathrm{C}(1 \mathrm{x})$ & 13.0 & $*$ & 11.8 & * & 28.0 & $*$ \\
\hline & $M-C(2 x)$ & 14.9 & * & 11.8 & * & 31.5 & $*$ \\
\hline & $S-C(1 x)$ & 9.1 & & 10.0 & * & 32.0 & * \\
\hline & S-C $(2 x)$ & 12.1 & & 14.8 & $*$ & 37.2 & $*$ \\
\hline & MB-C (1x) & 11.1 & & 14.3 & $*$ & 32.6 & $*$ \\
\hline & MB-C (2x) & 10.8 & & 10.8 & $*$ & 36.2 & $*$ \\
\hline \multirow{2}{*}{ Humic } & $\mathrm{H}-\mathrm{C}(1 \mathrm{x})$ & 8.9 & & 7.0 & & 30.6 & $*$ \\
\hline & $\mathrm{H}-\mathrm{C}(2 \mathrm{x})$ & 13 & $*$ & 8.3 & & 21.0 & \\
\hline \multirow{7}{*}{ Humic + Biofertilizer } & $\mathrm{N}-\mathrm{C}(1 \mathrm{x})$ & 11.4 & & 4.0 & & 3.4 & \\
\hline & $\mathrm{N}-\mathrm{C}(2 \mathrm{x})$ & 4.8 & & 4.5 & & 16.2 & \\
\hline & ML-C (1x) & 10.8 & & 9.0 & $*$ & 25.8 & $*$ \\
\hline & ML-C $(2 \mathrm{x})$ & 5.4 & & 1.3 & & 21.6 & $*$ \\
\hline & $\mathrm{M}+\mathrm{H}-\mathrm{C}(1 \mathrm{x}, 1 \mathrm{x})$ & 11.7 & & 6.8 & & 21.3 & \\
\hline & $\mathrm{S}+\mathrm{H}-\mathrm{C}(1 \mathrm{x}, 1 \mathrm{x})$ & 15.9 & $*$ & 8.8 & & 22.9 & $*$ \\
\hline & $\mathrm{MB}+\mathrm{H}-\mathrm{C}(1 \mathrm{x}, 1 \mathrm{x})$ & 15.6 & $*$ & 8.5 & & 21.9 & $*$ \\
\hline Actual Control values $(\mathrm{C})$ & & 33.3 & & 52.3 & & 102.5 & \\
\hline
\end{tabular}

Note. * denotes significant differences, $\alpha<0.05$.

$\mathrm{M}=$ Microgeo; $\mathrm{S}=$ SoilSoup; $\mathrm{MB}=$ Microgro Supreme Bio Inoculant; $\mathrm{H}=$ Microlife Humic; $\mathrm{N}=$ Nanobind; $\mathrm{ML}=$ Microlife 6-2-4; $\mathrm{C}=$ Control.

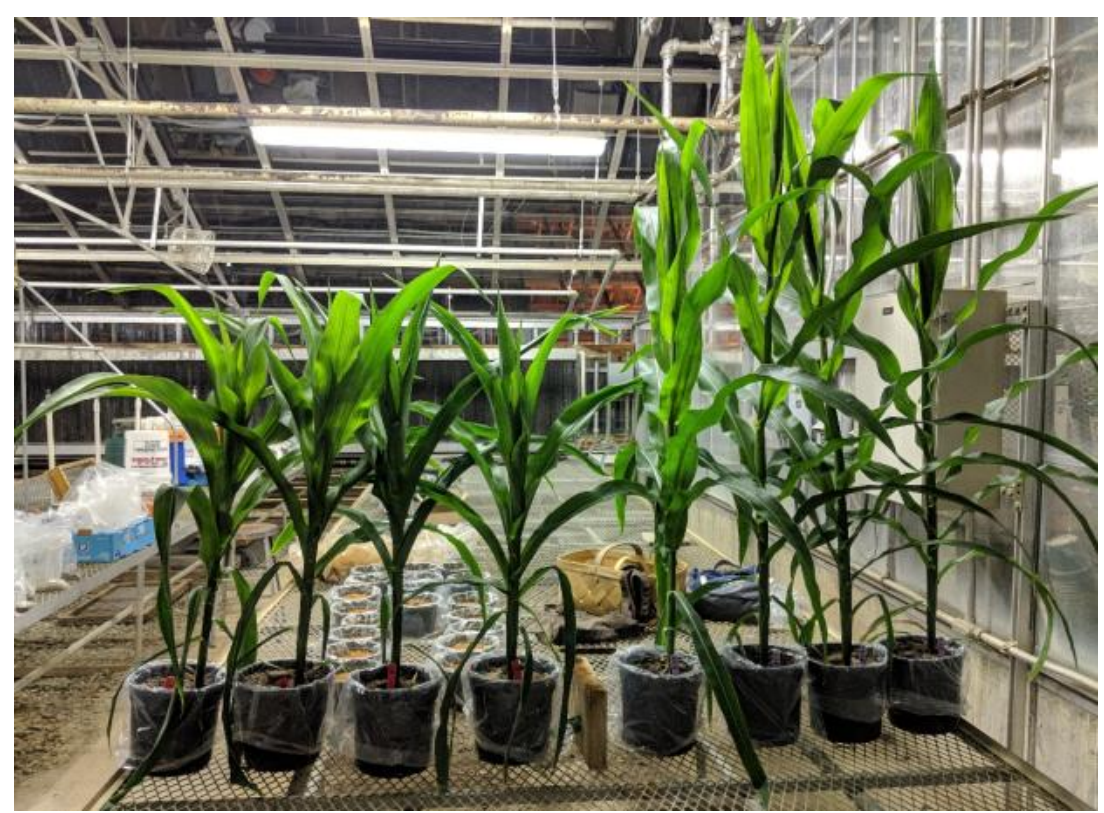

Figure 1. Plant height visual contrast between control (left) and Microgeo $2 \mathrm{x}$ treated plants (right) at 60 days post-emergence

\subsection{Chlorophyll Content (atLAEF) and Photosynthetic Efficiency $\left(F_{v} / F_{m}\right)$}

The total photosynthetic pigments or chlorophyll content has been used to assess the physiological status of plants and to detect stress conditions such as high salt level in soil (Taïbi et al., 2016) and drought (Zhang et al., 2011). The statistical significance of atLEAF values were less drastic than that of fluorometer (Table 3). 
Generally, atLEAF values did not differ between treatments and the control with some values lower than the control (Table 5). At 40 days PE, water content in the pots was dropped to $30 \%$ of field capacity and the treatments combining HA + biofertilizer had greater atLEAF values at 60 days PE in response (Table 5). This may indicate that corn plants receiving these treatments suffered less stress from water limitation. In contrast to our results where differences in indirect measures of chlorophyll content were scarce, other studies have reported that HA consistently increases chlorophyll content in potato leaf tissue (Selim, Shedeed, Asaad, \& El-Neklawy, 2012) and roselle (Hibiscus sabdariffa L.) (Sanjari, Sirousmehr, \& Fakheri, 2015) under hydric stress conditions. Azab (2016) revealed that biofertilizers alone and in combination with NPK increased chlorophyll content of corn under moderate, intermediate and severe water deficit. Also, the same study showed that biofertilizer $+50 \%$ NPK produced greater chlorophyll content than the application of biofertilizer $+100 \%$ NPK under normal irrigation and water deficit. Abdelraouf, El-Habbasha, Hozayn, and Hoballah (2013) found that the application of biofertilizer to wheat significantly increased total chlorophyll under $100 \%, 80 \%, 60 \%$ and $40 \%$ irrigation requirements compared to treatments without biofertilizer. Furthermore, to clarify the relationship between atLEAF and the actual chlorophyll content, devices that provide a non-destructive estimate of the amount of chlorophyll present in the plant leaf (Gianquinto et al., 2004) and strong relationships between these chlorophyll meters readings and the actual chlorophyll content in the leaves in many different crops (Pellizzaro, Ventura, Arca, \& Canu, 1998) including corn (Castelli, Contillo, \& Miceli, 1996; Markwell, Osterman, \& Mitchell, 1995) have been reported. The SPAD-502 Chlorophyll meter (Soil Plant Analysis Development, Minolta Camera Co., Ltd., Japan) is the most used device, however the atLEAF Chl meter (FT Green LLC, Wilmington, DE) used in this study can be an affordable alternative to the SPAD-502 meter (Zhu, Tremblay, \& Liang, 2012).

Photosynthetic efficiency values were higher than control values for most treatments in all three data collection periods (Table 6). A more energetic photosynthesis process could affect plant development such as greater plant height and biomass values measured in this study. According to Björkman and Demmig (1987) the optimal value of $\mathrm{F}_{\mathrm{v}} / \mathrm{F}_{\mathrm{m}}$ is around 0.83 for most species, depending on the developmental stage of the leaves, with lower values indicating plant stress. Thus, the photosynthetic efficiency readings collected in the most mature period (60 days $\mathrm{PE})$ showed that the treatments presenting significant differences between control were much closer to the optimal/non-stress threshold. Lotfi et al. (2018) tested the effects of HA on photosynthetic efficiency of rapeseed (Brassica napus subsp. napus) plants in different water regimes and the application of HA resulted in increased maximum quantum yield of PSII photochemistry $\left(\mathrm{F}_{\mathrm{v}} / \mathrm{F}_{\mathrm{m}}\right)$, where the highest discrepancy between non-humic acid and HA treatments appeared in response to the most severe water stress. Shool and Shamshiri (2014) tested the interaction effect of mycorrhizal fungi Glomus mosseae and the bacterial strain Pseudomonas fluorescens $\mathrm{P}_{52}$ in pistachio (Pistacia vera) cv. Qazvini plants under water regimes of $100 \%, 75 \%, 50 \%$ and $25 \%$ of field capacity and the highest discrepancy of $\mathrm{F}_{\mathrm{v}} / \mathrm{F}_{\mathrm{m}}$ values between non-biological and biological fertilization appeared in the treatments managed under $25 \%$ of field capacity.

The chlorophyll works as a photoreceptor in photosynthesis, thus there are studies showing the correlation between total chlorophyll content and $\mathrm{F}_{\mathrm{v}} / \mathrm{F}_{\mathrm{m}}$ in aloe vera (Aloe vera) (Hazrati, Tahmasebi-Sarvestani, Modarres-Sanavy, Mokhtassi-Bidgoli, \& Nicola, 2016), olive tree (Olea europaea) (Khaleghi, Arzani, Moallemi, \& Barzegar, 2012) and wheat (Sharma, Andersen, Ottosen, \& Rosenqvist, 2015). These studies showed lower values of total chlorophyll and $\mathrm{F}_{\mathrm{v}} / \mathrm{F}_{\mathrm{m}}$ during water or heat stress and higher values when the plants were experiencing ideal conditions. When comparing these previous studies with this current study, we found similar relationships for chlorophyll content and $\mathrm{F}_{\mathrm{v}} / \mathrm{F}_{\mathrm{m}}$. However, the chlorophyll content and $\mathrm{F}_{\mathrm{v}} / \mathrm{F}_{\mathrm{m}}$ relationships in our study were not as evident as the values presented in the three studies mentioned before. In fact, the difference between control and treatments was more evident in the $\mathrm{F}_{\mathrm{v}} / \mathrm{F}_{\mathrm{m}}$ than atLEAF / chlorophyll content readings (Tables 5 and 6). 
Table 5. atLEAF readings represented by the actual control values and the difference between treatment and control values

\begin{tabular}{|c|c|c|c|c|c|c|}
\hline \multirow{2}{*}{ Category } & \multirow{2}{*}{ Treatment comparison } & \multicolumn{5}{|c|}{ Difference between treatments and control values } \\
\hline & & 20 days $\mathrm{PE}$ & \multicolumn{2}{|c|}{40 days $P E$} & \multicolumn{2}{|c|}{60 days $\mathrm{PE}$} \\
\hline & & ------------- & --- atL & $\mathrm{AF}$, & \multirow{2}{*}{\multicolumn{2}{|c|}{2.08}} \\
\hline \multirow{6}{*}{ Biofertilizer } & $\mathrm{M}-\mathrm{C}(1 \mathrm{x})$ & 3.63 & 7.73 & \multirow{6}{*}{ * } & & \\
\hline & $\mathrm{M}-\mathrm{C}(2 \mathrm{x})$ & 2.95 & 5.55 & & \multicolumn{2}{|l|}{1.93} \\
\hline & $\mathrm{S}-\mathrm{C}(1 \mathrm{x})$ & 5.10 & 7.20 & & \multicolumn{2}{|l|}{3.53} \\
\hline & S-C $(2 x)$ & 4.15 & 6.70 & & \multicolumn{2}{|l|}{1.33} \\
\hline & MB-C (1x) & 3.85 & 7.92 & & \multicolumn{2}{|l|}{3.03} \\
\hline & MB-C (2x) & 5.08 & 5.33 & & \multicolumn{2}{|l|}{3.93} \\
\hline \multirow{2}{*}{ Humic } & $\mathrm{H}-\mathrm{C}(1 \mathrm{x})$ & 7.28 & \multicolumn{2}{|l|}{5.30} & \multicolumn{2}{|l|}{4.15} \\
\hline & $\mathrm{H}-\mathrm{C}(2 \mathrm{x})$ & -0.03 & \multicolumn{2}{|l|}{6.88} & \multicolumn{2}{|l|}{3.93} \\
\hline \multirow{7}{*}{ Humic + Biofertilizer } & $\mathrm{N}-\mathrm{C}(1 \mathrm{x})$ & -2.48 & \multicolumn{2}{|l|}{3.15} & \multicolumn{2}{|l|}{2.83} \\
\hline & $\mathrm{N}-\mathrm{C}(2 \mathrm{x})$ & 9.08 & \multicolumn{2}{|l|}{4.45} & \multicolumn{2}{|l|}{4.03} \\
\hline & ML-C (1x) & 8.03 & 5.93 & & 4.98 & $*$ \\
\hline & ML-C (2x) & 8.80 & 5.20 & & 1.48 & \\
\hline & $\mathrm{M}+\mathrm{H}-\mathrm{C}(1 \mathrm{x}, 1 \mathrm{x})$ & 6.78 & 7.48 & & 4.80 & $*$ \\
\hline & $\mathrm{S}+\mathrm{H}-\mathrm{C}(1 \mathrm{x}, 1 \mathrm{x})$ & 10.15 & 10.02 & $*$ & 4.87 & $*$ \\
\hline & $\mathrm{MB}+\mathrm{H}-\mathrm{C}(1 \mathrm{x}, 1 \mathrm{x})$ & 6.20 & 6.98 & & 4.30 & $*$ \\
\hline Actual Control Values & & 52.23 & 47.85 & & 60.88 & \\
\hline
\end{tabular}

Note. ${ }^{*}$ denotes significant differences, $\alpha<0.05$.

$\mathrm{M}=$ Microgeo; $\mathrm{S}=$ SoilSoup; $\mathrm{MB}=$ Microgro Supreme Bio Inoculant; $\mathrm{H}=$ Microlife Humic; $\mathrm{N}=$ Nanobind; $\mathrm{ML}=$ Microlife 6-2-4; $\mathrm{C}=$ Control.

Table 6. OS-50II fluorometer readings (Photosynthetic efficiency) represented by the actual control values and the difference between treatment and control values

\begin{tabular}{|c|c|c|c|c|c|c|c|}
\hline \multirow{2}{*}{ Category } & \multirow{2}{*}{ Treatment comparison } & \multicolumn{6}{|c|}{ Difference between treatments and control values } \\
\hline & & \multicolumn{2}{|c|}{20 days $\mathrm{PE}$} & \multicolumn{2}{|c|}{40 days $\mathrm{PE}$} & \multicolumn{2}{|c|}{60 days $\mathrm{PE}$} \\
\hline & & ------- & 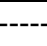 & Fluoro & eter & -------. & - \\
\hline \multirow{6}{*}{ Biofertilizer } & $\mathrm{M}-\mathrm{C}(1 \mathrm{x})$ & 0.258 & * & 0.112 & $*$ & 0.057 & * \\
\hline & $\mathrm{M}-\mathrm{C}(2 \mathrm{x})$ & 0.260 & * & 0.123 & * & 0.070 & * \\
\hline & S-C (1x) & 0.125 & * & 0.048 & & 0.008 & \\
\hline & $S-C(2 x)$ & 0.136 & * & 0.049 & & 0.003 & \\
\hline & MB-C (1x) & 0.248 & * & 0.117 & $*$ & 0.074 & * \\
\hline & MB-C (2x) & 0.272 & $*$ & 0.129 & * & 0.069 & * \\
\hline \multirow{2}{*}{ Humic } & $\mathrm{H}-\mathrm{C}(1 \mathrm{x})$ & 0.238 & $*$ & 0.131 & $*$ & 0.031 & \\
\hline & $\mathrm{H}-\mathrm{C}(2 \mathrm{x})$ & 0.211 & * & 0.106 & $*$ & 0.031 & \\
\hline \multirow{7}{*}{ Humic + Biofertilizer } & $\mathrm{N}-\mathrm{C}(1 \mathrm{x})$ & 0.134 & $*$ & 0.101 & $*$ & 0.013 & \\
\hline & $\mathrm{N}-\mathrm{C}(2 \mathrm{x})$ & 0.159 & $*$ & 0.069 & $*$ & 0.006 & \\
\hline & ML-C (1x) & 0.248 & $*$ & 0.114 & * & 0.070 & * \\
\hline & ML-C (2x) & 0.246 & $*$ & 0.133 & $*$ & 0.049 & $*$ \\
\hline & $\mathrm{M}+\mathrm{H}-\mathrm{C}(1 \mathrm{x}, 1 \mathrm{x})$ & 0.311 & $*$ & 0.136 & $*$ & 0.071 & $*$ \\
\hline & $\mathrm{S}+\mathrm{H}-\mathrm{C}(1 \mathrm{x}, 1 \mathrm{x})$ & 0.225 & $*$ & 0.113 & $*$ & 0.046 & $*$ \\
\hline & $\mathrm{MB}+\mathrm{H}-\mathrm{C}(1 \mathrm{x}, 1 \mathrm{x})$ & 0.289 & * & 0.130 & $*$ & 0.070 & * \\
\hline \multicolumn{2}{|c|}{ Actual Control Values (C) } & 0.489 & & 0.669 & & 0.742 & \\
\hline
\end{tabular}

Note. ${ }^{*}$ denotes significant differences, $\alpha<0.05$.

$\mathrm{M}=$ Microgeo; $\mathrm{S}=$ SoilSoup; $\mathrm{MB}=$ Microgro Supreme Bio Inoculant; $\mathrm{H}=$ Microlife Humic; $\mathrm{N}=$ Nanobind; $\mathrm{ML}=$ Microlife 6-2-4; $\mathrm{C}=$ Control. 


\subsection{Plant Biomass}

Final shoot, root and total dry biomass were all significantly affected by IPNS treatment (Table 3). The greatest effect of IPNS treatment occurred for root biomass receiving HA treatments and shoot biomass receiving the biofertilizer treatments (Table 7). Total biomass was also affected by most of the treatments, where only 3 treatments did not present significantly higher value than control. Previous studies have reported increased shoot and root biomass when HA and/or biofertilizers were applied, especially under stress conditions (Dimkpa, Weinand, \& Asch, 2009; Prado et al., 2016).

Shoot and root dry weight are commonly used to measure the effects of humic substances (Chen \& Aviad, 1990) and in this corn study, the HA treatments resulted in the greatest root biomass. Chen and Aviad (1990) mentioned that the increased root growth promoted by HA is generally more evident than shoot growth, which is also what we observed in the current study. Other researchers have documented increased root biomass when HA was applied in soybeans (Prado et al., 2016), lettuce (Young \& Chen, 1997), bentgrass (Agrostis palutris) (Dorer \& Peacock, 1997), forage turnips (Brassica rapa L.) (Albayrak \& Camas, 2005) and tomato (Adani, Genevini, Zaccheo, \& Zocchi, 1998). In contrast, (Hartz \& Bottoms, 2010) tested five commercial HA formulas and found no significant effect on tomato dry mass accumulation. Therefore, the effectiveness of HA will depend on product rate, severity of stress, organic matter content of the soil, HA composition and extraction method. According to Tahiri et al. (2015), humic substances influence two main mechanisms of plant growth: improvement of nutrient availability and phyto-stimulation. The use of HA enhanced the adsorption of macro and micro nutrients of gerbera (Nikbakht et al., 2008) and the presence of physiologically active concentrations of cytokinin in humic substances was demonstrated in a study using radish (Raphanus sativus L.) and corn plants (Pizzeghello, Francioso, Ertani, Muscolo, \& Nardi, 2013). Though the effects of humic substances on root biomass have solid evidence, a number of studies also present beneficial effects of HA on length and fresh and dry weight of shoots (Nardi, Carletti, Pizzeghello, \& Muscolo, 2009).

Biofertilizers most often affected shoot biomass (Table 7). Previous studies have reported significant increases in shoot dry biomass for wheat (Singh \& Prasad, 2011), rice (Oryza sativa L.) (Yuwono, Handayani, \& Soedarsono, 2005) and lettuce (Kohler, Caravaca, \& Roldán, 2010) when various biofertilizers were applied. Application of biofertilizers derived from vermicompost tea also outperformed the control in terms of shoot biomass on tomatoes (Edwards, Arancon, \& Greytak, 2006; Fritz, Franke-Whittle, Haindl, Insam, \& Braun, 2012). The plant growth effects caused by the use of biofertilizers have been attributed to increased microbial population, biologically active substances and nutrition promotion by accelerating mineralization processes (Rodríguez \& Fraga, 1999; Somers, Vanderleyden, \& Srinivasan, 2004). It was also postulated that the growth stimulation might be due to the phytohormones synthesizing as auxins (Dobbelaere, Croonenborghs, Thys, Broek, \& Vanderleyden, 1999), gibberellic acids (Turan et al., 2014), and cytokinins (Zhang et al., 2014). Biofertilizer treatments alone affect root biomass to a much lesser extent comparing to the other materials (Table 7), however there are several studies showing the benefits of biofertilizers on root growth in several crops (Bhardwaj, Ansari, Sahoo, \& Tuteja, 2014) and wheat (Dobbelaere et al., 1999).

In general, the use of HA and/or biofertilizers increased total plant biomass compared to the control, however the integrated use of these compounds interestingly resulted in plants with more proportional above/belowground biomass ratio. A lower shoot:root ratio (Table 7) could indicate greater stress tolerance at a more mature growth stage because a proportional root system may have improved ability to send nutrients/water to the aboveground biomass. In both greenhouse and field trials, Canellas et al. (2013) validated a synergistic effect of biofertilizer and HA, where corn grain yield was $45 \%$ and $48 \%$ higher with the integrated use of both compounds when comparing with the independent use of biofertilizer and HA, respectively. 
Table 7. Shoot, root and total dry biomass readings represented by the actual control values and the difference between treatment and control values. Shoot-root ratio is an absolute value

\begin{tabular}{|c|c|c|c|c|c|c|c|c|}
\hline \multirow{2}{*}{ Category } & \multirow{2}{*}{ Treatment comparison } & \multicolumn{7}{|c|}{ Difference between treatments and control values } \\
\hline & & \multicolumn{2}{|c|}{ Shoot biomass } & \multicolumn{2}{|c|}{ Root biomass } & \multicolumn{2}{|c|}{ Total biomass } & \multirow{2}{*}{ Shoot-root ratio } \\
\hline \multirow{7}{*}{ Biofertilizer } & & ----- & ---- & ----- & ----1 & g ------- & ---- & \\
\hline & $\mathrm{M}-\mathrm{C}(1 \mathrm{x})$ & 25.25 & $*$ & 4.65 & $*$ & 29.90 & $*$ & 3.77 \\
\hline & $M-C(2 x)$ & 33.80 & $*$ & 2.23 & & 36.03 & $*$ & 4.92 \\
\hline & S-C $(1 \mathrm{x})$ & 34.75 & $*$ & 1.68 & & 36.43 & $*$ & 5.17 \\
\hline & S-C (2x) & 33.67 & $*$ & 0.25 & & 33.92 & $*$ & 5.63 \\
\hline & MB-C (1x) & 24.72 & $*$ & 1.65 & & 26.37 & $*$ & 4.50 \\
\hline & MB-C $(2 x)$ & 13.33 & & 2.38 & & 15.71 & & 3.56 \\
\hline \multirow{2}{*}{ Humic } & $\mathrm{H}-\mathrm{C}(1 \mathrm{x})$ & 18.60 & & 6.25 & $*$ & 24.85 & $*$ & 3.12 \\
\hline & $\mathrm{H}-\mathrm{C}(2 \mathrm{x})$ & 11.78 & & 7.02 & * & 18.80 & & 2.66 \\
\hline \multirow{7}{*}{ Humic + Biofertilizer } & $\mathrm{N}-\mathrm{C}(1 \mathrm{x})$ & 14.13 & & 6.60 & $*$ & 20.73 & $*$ & 2.84 \\
\hline & $\mathrm{N}-\mathrm{C}(2 \mathrm{x})$ & 8.08 & & 6.00 & * & 14.08 & & 2.61 \\
\hline & ML-C (1x) & 24.67 & $*$ & 5.57 & * & 30.24 & $*$ & 3.56 \\
\hline & ML-C (2x) & 13.00 & & 3.40 & & 16.40 & & 3.32 \\
\hline & $\mathrm{M}+\mathrm{H}-\mathrm{C}(1 \mathrm{x}, 1 \mathrm{x})$ & 12.10 & & 8.77 & $*$ & 20.87 & $*$ & 2.47 \\
\hline & $\mathrm{S}+\mathrm{H}-\mathrm{C}(1 \mathrm{x}, 1 \mathrm{x})$ & 17.90 & & 6.95 & $*$ & 24.85 & $*$ & 2.98 \\
\hline & $\mathrm{MB}+\mathrm{H}-\mathrm{C}(1 \mathrm{x}, 1 \mathrm{x})$ & 12.28 & & 12.27 & $*$ & 24.55 & $*$ & 2.13 \\
\hline \multicolumn{2}{|c|}{ Actual Control Values (C) } & 42.10 & & 13.23 & & 55.33 & & 3.19 \\
\hline
\end{tabular}

Note. ${ }^{*}$ denotes significant differences, $\alpha<0.05$.

$\mathrm{M}=$ Microgeo; $\mathrm{S}=$ SoilSoup; $\mathrm{MB}=$ Microgro Supreme Bio Inoculant; $\mathrm{H}=$ Microlife Humic; $\mathrm{N}=$ Nanobind; $\mathrm{ML}=$ Microlife 6-2-4; $\mathrm{C}=$ Control.

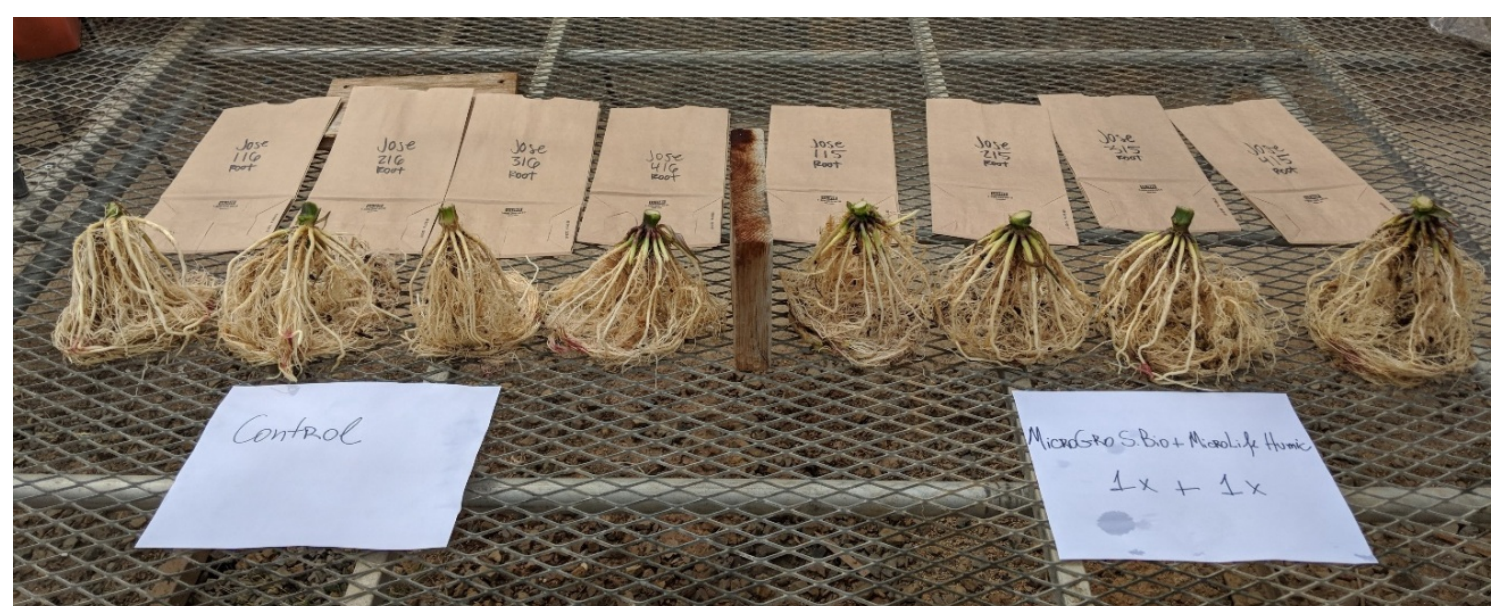

Figure 2. Root biomass visual contrast between control (left) and Microgro Supreme Bio Inoculant + Microlife Humic (right)

\subsection{Differences between the Two Application Rates of the Same Product}

The treatments using only one product were tested at $1 \mathrm{x}$ and $2 \mathrm{x}$ the label rate per application. The statistically significant differences between the two application rates $(1 \mathrm{x}$ and $2 \mathrm{x})$ were scarce considering the products tested and parameters collected. MicroLife 6-2-4 at the lower rate (1x) resulted in greater differences in total biomass, plant height (40 days PE) and atLeaf (60 days PE) (Table 8). Lower rates (1x) of Microlife humic produced greater atLEAF values at (20 days PE) (Table 8 ). The only product where doubling the rate generated significant greater difference was the application of Nanobind (2x) on atLEAF (20 days PE) (Table 8$)$. Thus, it might be reasonable to affirm that the companies are providing a proper label rate for each product considering the two rates tested in this study. Nikbakht et al. (2008) have tested five different levels of HA and found that higher 
levels decreased absorption of some nutrients, confirming the importance of suitable application rate. Furthermore, Vallini, Pera, Avio, Valdrighi, and Giovannetti (1993) found the optimal dose of humic acid + Glomus mosseae and the treatments where HA concentration was above the optimal dose the laurel (Laurus nobilis L.) shoot and root fresh weight decreased to values lower than the control in which no HA was applied.

Table 8. Plant height contrast between $1 \mathrm{x}$ and $2 \mathrm{x}$ of the label application rate

\begin{tabular}{|c|c|c|c|c|c|c|c|c|c|}
\hline \multirow{2}{*}{ Product } & \multicolumn{3}{|c|}{ Plant height } & \multicolumn{3}{|c|}{ atLEAF } & \multirow{2}{*}{$\begin{array}{l}\text { Shoot } \\
\text { biomass }\end{array}$} & \multirow{2}{*}{$\begin{array}{l}\text { Root } \\
\text { biomass }\end{array}$} & \multirow{2}{*}{$\begin{array}{l}\text { Total } \\
\text { biomass }\end{array}$} \\
\hline & 20 days & 40 days & 60 days & 20 days & 40 days & 60 days & & & \\
\hline & \multicolumn{9}{|c|}{ 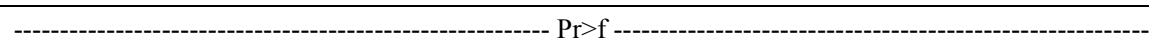 } \\
\hline Microgeo 1x vs. $2 \mathrm{x}$ & 0.659 & 1.000 & 0.631 & 0.833 & 0.420 & 0.917 & 0.194 & 0.070 & 0.376 \\
\hline SoilSoup $1 \mathrm{x}$ vs. $2 \mathrm{x}$ & 0.490 & 0.120 & 0.482 & 0.767 & 0.852 & 0.129 & 0.869 & 0.281 & 0.717 \\
\hline MicroGro Bioinoculant $1 \mathrm{x}$ vs. $2 \mathrm{x}$ & 0.941 & 0.249 & 0.629 & 0.702 & 0.336 & 0.531 & 0.086 & 0.582 & 0.126 \\
\hline MicroLife Humic 1x vs. 2x & 0.305 & 0.678 & 0.196 & $0.026 *$ & 0.559 & 0.875 & 0.298 & 0.556 & 0.382 \\
\hline Nanobind $1 \mathrm{x}$ vs. $2 \mathrm{x}$ & 0.127 & 0.868 & 0.084 & $0.001 *$ & 0.629 & 0.404 & 0.356 & 0.648 & 0.337 \\
\hline MicroLife $6-2-41 x$ vs. $2 x$ & 0.215 & $0.013 *$ & 0.568 & 0.809 & 0.787 & $0.018 *$ & 0.079 & 0.103 & $0.049 *$ \\
\hline
\end{tabular}

Note. $*$ denotes significant differences, $\alpha<0.05$.

\subsection{Substrate-Induced Respiration (SIR)}

Substrate-induced respiration uses the physiological respiration reactions of the microorganisms from the soil to measure microbial activity (Anderson \& Domsch, 1978). According to Swaina, Bastiraya, Jitendraa, and Haibrub (2014), the SIR method offers a reliable and easy assessment of the microbial biomass and other aspects of microbial growth in the soil. The use of this method to evaluate the treatments tested in this study showed statistically significant differences (Table 9). Though SIR was positive for 11 of 15 IPNS treatments, only two treatments were significantly higher than the control (Table 10) and responses in general did not follow the same trend as the plant parameters. The two rates of Microgro Supreme Bioinoculant were the only treatments with SIR values greater than the control. Khan et al. (2015) reported a study testing different bioinoculants and vermicompost in combination and alone, where all treatments had higher soil respiration values than the control which did not receive bioinoculants and vermicompost. Moreover, the same study presented soil respiration increment varying from $29.4 \%$ to $53.6 \%$ over the control value, depending on the treatment.

Application of HA did not significantly affect the SIR results. Hartz and Bottoms (2010) tested the effects of HA on microbial respiration in two different soils containing high and low organic matter. In their study, the addition of HA enhanced microbial respiration only in the low organic matter soil. Therefore, the high organic matter content present in our soil media may have decreased any potential HA influence on microbial respiration.

Table 9. Analysis of variance of the IPNS treatments on substrate-induced respiration

\begin{tabular}{ll}
\hline Source & CIR \\
\hline & $\operatorname{Pr}>\mathrm{f}$ \\
Rep & 0.1012 \\
Treatment & 0.00 \\
CV & 50.0 \\
SED & 2.9 \\
\hline
\end{tabular}


Table 10. Substrate-induced respiration (SIR) values represented by the actual control values and the difference between treatment and control values

\begin{tabular}{|c|c|c|}
\hline \multirow{2}{*}{ Category } & \multirow{2}{*}{ Treatment comparison } & Difference between treatments and control values \\
\hline & & Substrate-induced respiration (SIR) \\
\hline \multirow{7}{*}{ Biofertilizer } & & ug $\mathrm{CO}_{2} / \mathrm{g}$ dry soil/hour \\
\hline & M-C (1x) & -0.50 \\
\hline & M-C (2x) & 0.40 \\
\hline & S-C (1x) & 0.10 \\
\hline & S-C (2x) & 0.20 \\
\hline & MB-C (1x) & 9.10 \\
\hline & MB-C (2x) & 5.80 \\
\hline \multirow{2}{*}{ Humic } & $\mathrm{H}-\mathrm{C}(1 \mathrm{x})$ & -0.70 \\
\hline & H-C (2x) & -0.20 \\
\hline \multirow{7}{*}{ Humic + Biofertilizer } & $\mathrm{N}-\mathrm{C}(1 \mathrm{x})$ & $0.20^{-}$ \\
\hline & $\mathrm{N}-\mathrm{C}(2 \mathrm{x})$ & -0.20 \\
\hline & ML-C (1x) & 1.00 \\
\hline & ML-C (2x) & 1.60 \\
\hline & $\mathrm{M}+\mathrm{H}-\mathrm{C}(1 \mathrm{x}, 1 \mathrm{x})$ & 0.10 \\
\hline & $\mathrm{S}+\mathrm{H}-\mathrm{C}(1 \mathrm{x}, 1 \mathrm{x})$ & 0.90 \\
\hline & $\mathrm{MB}+\mathrm{H}-\mathrm{C}(1 \mathrm{x}, 1 \mathrm{x})$ & 2.90 \\
\hline \multicolumn{2}{|c|}{ Actual Control Values $(\mathrm{C})$} & 4.50 \\
\hline
\end{tabular}

Note. ${ }^{*}$ denotes significant differences, $\alpha<0.01$.

\section{Conclusions}

The individual and combined use of HA and biofertilizers generally increase corn growth and development parameters under the conditions of this study. Though all pots received adequate synthetic fertilizer, the control plants were generally smaller and less vigorous compared to the plants receiving either HA or biofertilizer treatments, but no additive benefit was observed for the integrated practice compared to individual applications. At 40 and 60 days PE the biofertilizer products consistently produced plants that were taller than the control. In general, shoot dry matter was increased by the biofertilizer products, while root dry matter was most positively affected by HA products. Impacts on total biomass were mixed based on contributions of increased root biomass, shoot biomass or both with 11 of 15 treatments exhibiting greater total biomass than the control. Differences in atLeaf chlorophyll meter readings were uncommon for any treatment in our study. However, all treatments had higher fluorometer readings at 20 days PE and higher readings for 13 of 15 treatments at 40 days PE. Although the current study cannot affirm that the conjunctive use of HA and biofertilizers is a better practice than the application of each compound alone, we did find positive benefits from the application of these compounds to corn. Further studies addressing different types and levels of stress and greater stress duration should be conducted to validate these findings and contribute further understanding of the value of the IPNS approach.

\section{Acknowledgements}

The authors are grateful to the School of Plant and Environmental Sciences of Virginia Polytechnic Institute and State University and the Virginia Agricultural Experiment Station.

\section{References}

Abdelraouf, R., El-Habbasha, S., Hozayn, M., \& Hoballah, E. (2013). Water stress mitigation on growth, yield and quality traits of wheat (Triticum aestivum L.) using biofertilizer inoculation. Journal of Applied Sciences Research, 9(3), 2135-2145.

Abendroth, L. J., Elmore, R. W., Boyer, M. J., \& Marlay, S. K. (2011). Corn Growth and Development (PMR 1009). Iowa State University Extension.

Adani, F., Genevini, P., Zaccheo, P., \& Zocchi, G. (1998). The effect of commercial humic acid on tomato plant growth and mineral nutrition. Journal of Plant Nutrition, 21(3), 561-575. https://doi.org/10.1080/ 01904169809365424

Adesemoye, A., Torbert, H., \& Kloepper, J. (2008). Enhanced plant nutrient use efficiency with PGPR and AMF in an integrated nutrient management system. Canadian Journal of Microbiology, 54(10), 876-886. https://doi.org/10.1139/W08-081 
Aftab, A., \& Asghari, B. (2008). Rhizobium and phosphate solubilizing bacteria improve the yield and phosphorus uptake in wheat (Triticum aestivum). International Journal of Agriculture and Biology, 10(1), 85-88.

Albayrak, S., \& Camas, N. (2005). Effects of different levels and application times of humic acid on root and leaf yield and yield components of forage turnip (Brassica rapa L.). Journal of Agronomy, 4(2), 130-133. https://doi.org/10.3923/ja.2005.130.133

Albiach, R., Canet, R., Pomares, F., \& Ingelmo, F. (2001). Organic matter components, aggregate stability and biological activity in a horticultural soil fertilized with different rates of two sewage sludges during ten years. Bioresource Technology, 77(2), 109-114. https://doi.org/10.1016/S0960-8524(00)00166-8

Anderson, J., \& Domsch, K. (1978). A physiological method for the quantitative measurement of microbial biomass in soils. Soil Biology and Biochemistry, 10(3), 215-221. https://doi.org/10.1016/0038-0717(78) 90099-8

Aulakh, M. S., \& Grant, C. A. (2008). Integrated nutrient management for sustainable crop production. CRC Press. https://doi.org/10.1201/9781439828465.ch7

Azab, E. (2016). Effect of water stress and biological fertilization on maize growth, chemical composition and productivity in calcareous soil. American Journal of Plant Physiology, 11, 1-11. https://doi.org/10.3923/ ajpp.2016.1.11

Baldotto, L. E., \& Baldotto, M. A. (2014). Adventitious rooting on the Brazilian red-cloak and sanchezia after application of indole-butyric and humic acids. Horticultura Brasileira, 32, 434-439. https://doi.org/10.1590/ S0102-053620140000400010

Bhardwaj, D., Ansari, M. W., Sahoo, R. K., \& Tuteja, N. (2014). Biofertilizers function as key player in sustainable agriculture by improving soil fertility, plant tolerance and crop productivity. Microbial Cell Factories, 13(1), 66. https://doi.org/10.1186/1475-2859-13-66

Bhattacharyya, P. N., \& Jha, D. K. (2012). Plant growth-promoting rhizobacteria (PGPR): Emergence in agriculture. World Journal of Microbiology and Biotechnology, 28(4), 1327-1350. https://doi.org/10.1007/ s11274-011-0979-9

Bianciotto, V., \& Bonfante, P. (2002). Arbuscular mycorrhizal fungi: A specialised niche for rhizospheric and endocellular bacteria. Antonie van Leeuwenhoek, 81(1), 365-371. https://doi.org/10.1023/A:1020544919072

Björkman, O., \& Demmig, B. (1987). Photon yield of O2 evolution and chlorophyll fluorescence characteristics at $77 \mathrm{~K}$ among vascular plants of diverse origins. Planta, 170(4), 489-504. https://doi.org/10.1007/ BF00402983

Bokhtiar, S., \& Sakurai, K. (2005). Effects of organic manure and chemical fertilizer on soil fertility and productivity of plant and ratoon crops of sugarcane. Archives of Agronomy and Soil Science, 51(3), 325-334. https://doi.org/10.1080/03650340500098006

Brannon, C. A., \& Sommers, L. E. (1985). Preparation and characterization of model humic polymers containing organic phosphorus. Soil Biology and Biochemistry, 17(2), 213-219. https://doi.org/10.1016/0038-0717 (85)90117-8

Brownell, J. R., Nordstrom, G., Marihart, J., \& Jorgensen, G. (1987). Crop responses from two new leonardite extracts (Vol. 62). https://doi.org/10.1016/0048-9697(87)90544-4

Cakmak, I. (2002). Plant nutrition research: Priorities to meet human needs for food in sustainable ways. Plant and Soil, 247(1), 3-24. https://doi.org/10.1023/A:1021194511492

Canellas, L. P., Balmori, D. M., Médici, L. O., Aguiar, N. O., Campostrini, E., Rosa, R. C. C., ... Olivares, F. L. (2013). A combination of humic substances and Herbaspirillum seropedicae inoculation enhances the growth of maize (Zea mays L.). Plant and Soil, 366(1), 119-132. https://doi.org/10.1007/s11104-012$1382-5$

Castelli, F., Contillo, R., \& Miceli, F. (1996). Non-destructive determination of leaf chlorophyll content in four crop species 1. Journal of Agronomy and Crop Science, 177(4), 275-283. https://oi.org/10.1111/ j.1439-037X.1996.tb00246.X

Chang, L., Wu, Y., Xu, W., Nikbakht, A., \& Xia, Y. (2012). Effects of calcium and humic acid treatment on the growth and nutrient uptake of Oriental lily. African Journal of Biotechnology, 11(9), 2218-2222. https://doi.org/10.5897/AJB11.1633 
Chauhan, H., Bagyaraj, D. J., Selvakumar, G., \& Sundaram, S. P. (2015). Novel plant growth promoting rhizobacteria-Prospects and potential. Applied Soil Ecology, 95, 38-53. https://doi.org/10.1016/j.apsoil. 2015.05.011

Chen, J. H. (2006). The combined use of chemical and organic fertilizers and/or biofertilizer for crop growth and soil fertility. Paper presented at the International Workshop on Sustained Management of the soil-rhizosphere system for efficient crop production and fertilizer use.

Chen, S. (2015). Evaluation of compost topdressing, compost tea and cultivation on tall fescue quality, soil physical properties and soil microbial activity (Thesis submitted to the Faculty of the Graduate School of theUniversity of Maryland, College Park, USA). https://doi.org/10.13016/M22F0R

Chen, Y., \& Aviad, T. (1990). Effects of Humic Substances on Plant Growth 1. In P. MacCarthy, C. E. Clapp, R. L. Malcolm, \& P. R. Bloom (Eds.), Humic Substances in Soil and Crop Sciences: Selected Readings (pp. 161-186). Madison, WI: Soil Science Society of America.

Chen, Y., Senesi, N., \& Schnitzer, M. (1977). Information provided on humic substances by E4/E6 ratios 1. Soil Science Society of America Journal, 41(2), 352-358. https://doi.org/10.2136/sssaj1977.036159950041000 $20037 x$

D’Andrea, P. A. (2002). Continuous liquid composting process-CLC and biofertilizer. Microbiol Industry and Trade LTDA.

Dimkpa, C., Weinand, T., \& Asch, F. (2009). Plant-rhizobacteria interactions alleviate abiotic stress conditions. Plant, Cell \& Environment, 32(12), 1682-1694. https://doi.org/10.1111/j.1365-3040.2009.02028.x

Dobbelaere, S., Croonenborghs, A., Thys, A., Broek, A. V., \& Vanderleyden, J. (1999). Phytostimulatory effect of Azospirillum brasilense wild type and mutant strains altered in IAA production on wheat. Plant and Soil, 212(2), 153-162. https://doi.org/10.1023/A:1004658000815

Dorer, S. P., \& Peacock, C. H. (1997). The effects of humate and organic fertilizer on establishment and nutrition of creeping bent putting greens. Intl. Turfgrass Soc. Res. J., 7, 437-443.

Dutta, S., Pal, R., Chakraborty, A., \& Chakrabarti, K. (2003). Influence of integrated plant nutrient supply system on soil quality restoration in a red and laterite soil: Einfluss integrierter pflanzennährstoff versorgung auf die wiederherstellun der bodenqualität von rotem und laterit boden. Archives of Agronomy and Soil Science, 49(6), 631-637. https://doi.org/10.1080/03650340310001599722

Edwards, C. A., Arancon, N. Q., \& Greytak, S. (2006). Effects of vermicompost teas on plant growth and disease. Biocycle, 47(5), 28.

Ferrara, G., \& Brunetti, G. (2010). Effects of the times of application of a soil humic acid on berry quality of table grape (Vitis vinifera L.) cv Italia. Spanish Journal of Agricultural Research, 8(3), 817. https://doi.org/ $10.5424 / 1283$

Fierer, N., Schimel, J. P., \& Holden, P. A. (2003). Variations in microbial community composition through two soil depth profiles. Soil Biology and Biochemistry, 35(1), 167-176. https://doi.org/10.1016/S0038-0717 (02)00251-1

Fritz, J., Franke-Whittle, I., Haindl, S., Insam, H., \& Braun, R. (2012). Microbiological community analysis of vermicompost tea and its influence on the growth of vegetables and cereals. Canadian Journal of Microbiology, 58(7), 836-847. https://doi.org/10.1139/w2012-061

Gaur, A. C., \& Bhardwaj, K. K. R. (1971). Influence of sodium humate on the crop plants inoculated with bacteria of agricultural importance. Plant and Soil, 35(1), 613-621. https://doi.org/10.1007/BF01372691

Gianquinto, G., Goffart, J. P., Olivier, M., Guarda, G., Colauzzi, M., Dalla Costa, L., ... Mackerron, D. K. L. (2004). The use of hand-held chlorophyll meters as a tool to assess the nitrogen status and to guide nitrogen fertilization of potato crop. Potato Research, 47(1), 35-80. https://doi.org/10.1007/BF02731970

Gryndler, M., Hršelová, H., Sudová, R., Gryndlerová, H., Řezáčová, V., \& Merhautová, V. (2005). Hyphal growth and mycorrhiza formation by the arbuscular mycorrhizal fungus Glomus claroideum BEG 23 is stimulated by humic substances. Mycorrhiza, 15(7), 483-488. https://doi.org/10.1007/s00572-005-0352-7

Hartz, T. K., \& Bottoms, T. G. (2010). Humic substances generally ineffective in improving vegetable crop nutrient uptake or productivity. HortScience, 45(6), 906-910. https://doi.org/10.21273/HORTSCI.45.6.906 
Hazrati, S., Tahmasebi-Sarvestani, Z., Modarres-Sanavy, S. A. M., Mokhtassi-Bidgoli, A., \& Nicola, S. (2016). Effects of water stress and light intensity on chlorophyll fluorescence parameters and pigments of Aloe vera L. Plant Physiology and Biochemistry, 106, 141-148. https://doi.org/10.1016/j.plaphy.2016.04.046

Hussain, T., Jilani, G., \& Iqbal, M. (1988). Integrated use of organic and inorganic N fertilizers in rice-wheat cropping system. Pakistan Journal of Soil Science, 23(6), 326-333. https://doi.org/10.1080/00380768. 1992.10416497

Joo, G.-J., Kim, Y.-M., Lee, I.-J., Song, K.-S., \& Rhee, I.-K. (2004). Growth promotion of red pepper plug seedlings and the production of gibberellins by Bacillus cereus, Bacillus macroides and Bacillus pumilus. Biotechnology Letters, 26(6), 487-491. https://doi.org/10.1023/B:BILE.0000019555.87121.34

Kaur, K., Kapoor, K. K., \& Gupta, A. P. (2005). Impact of organic manures with and without mineral fertilizers on soil chemical and biological properties under tropical conditions. Journal of Plant Nutrition and Soil Science, 168(1), 117-122. https://doi.org/10.1002/jpln.200421442

Khaleghi, E., Arzani, K., Moallemi, N., \& Barzegar, M. (2012). Evaluation of chlorophyll content and chlorophyll fluorescence parameters and relationships between chlorophyll a, b and chlorophyll content index under water stress in Olea europaea cv. Dezful. World Acad. Sci. Eng. Technol., 68, 1154-1157.

Khan, K., Pankaj, U., Verma, S. K., Gupta, A. K., Singh, R. P., \& Verma, R. K. (2015). Bio-inoculants and vermicompost influence on yield, quality of Andrographis paniculata, and soil properties. Industrial Crops and Products, 70, 404-409. https://doi.org/10.1016/j.indcrop.2015.03.066

Kim, M. J., Shim, C. K., Kim, Y. K., Hong, S. J., Park, J. H., Han, E. J., Kim, J. H., \& Kim, S. C. (2015). Effect of aerated compost tea on the growth promotion of lettuce, soybean, and sweet corn in organic cultivation. The Plant Pathology Journal, 31(3), 259. https://doi.org/10.5423/PPJ.OA.02.2015.0024

Kirkham, M. B. (2014). Chapter 10-Field Capacity, Wilting Point, Available Water, and the Nonlimiting Water Range. In M. B. Kirkham (Ed.), Principles of Soil and Plant Water Relations (2nd ed., pp. 153-170). Boston: Academic Press. https://doi.org/10.1016/B978-0-12-420022-7.00010-0

Kohler, J., Caravaca, F., \& Roldán, A. (2010). An AM fungus and a PGPR intensify the adverse effects of salinity on the stability of rhizosphere soil aggregates of Lactuca sativa. Soil Biology and Biochemistry, 42(3), 429-434. https://doi.org/10.1016/j.soilbio.2009.11.021

Kumwenda, J. D., Waddington, S. R., Snapp, S. S., Jones, R. B., \& Blackie, M. J. (1996). Soil fertility management research for the maize cropping systems of smallholders in southern Africa: A review.

Lotfi, R., Kalaji, H. M., Valizadeh, G. R., Khalilvand Behrozyar, E., Hemati, A., Gharavi-Kochebagh, P., \& Ghassemi, A. (2018). Effects of humic acid on photosynthetic efficiency of rapeseed plants growing under different watering conditions. Photosynthetica, 56(3), 962-970. https://doi.org/10.1007/s11099-017-0745-9

Lugtenberg, B., \& Kamilova, F. (2009). Plant-Growth-Promoting Rhizobacteria. Annual Review of Microbiology, 63(1), 541-556. https://doi.org/10.1146/annurev.micro.62.081307.162918

Mantelin, S., \& Touraine, B. (2004). Plant growth-promoting bacteria and nitrate availability: Impacts on root development and nitrate uptake. Journal of Experimental Botany, 55(394), 27-34. https://oi.org/10.1093/ jxb/erh010

Markwell, J., Osterman, J. C., \& Mitchell, J. L. (1995). Calibration of the Minolta SPAD-502 leaf chlorophyll meter. Photosynthesis Research, 46(3), 467-472. https://doi.org/10.1007/BF00032301

Mbagwu, J. S., \& Piccolo, A. (1997). Effects of humic substances from oxidized coal on soil chemical properties and maize yield. The role of humic substances in the ecosystems and in environmental protection (pp. 921-925). IHSS, Polish Society of Humic Substances, Wroclaw, Poland.

Mylonas, V. A., \& McCants, C. B. (1980). Effects of humic and fulvic acids on growth of tobacco. Plant and Soil, 54(3), 485-490. https://doi.org/10.1007/BF02181841

Nardi, S., Carletti, P., Pizzeghello, D., \& Muscolo, A. (2009). Biological activities of humic substances. Biophysico-chemical processes involving natural nonliving organic matter in environmental systems, 2 (Part 1, pp. 309-335). https://doi.org/10.1002/9780470494950.ch8

Nikbakht, A., Kafi, M., Babalar, M., Xia, Y. P., Luo, A., \& Etemadi, N.-A. (2008). Effect of humic acid on plant growth, nutrient uptake, and postharvest life of gerbera. Journal of Plant Nutrition, 31(12), 2155-2167. https://doi.org/10.1080/01904160802462819 
On, A., Wong, F., Ko, Q., Tweddell, R. J., Antoun, H., \& Avis, T. J. (2015). Antifungal effects of compost tea microorganisms on tomato pathogens. Biological Control, 80, 63-69. https://doi.org/10.1016/j.biocontrol. 2014.09.017

Pellizzaro, G., Ventura, A., Arca, B., \& Canu, A. (1998). A non-destructive method to determine leaf chlorophyll content in grain sorghum. Agricoltura Mediterranea, 128(4), 330-338.

Peoples, M. B., \& Craswell, E. T. (1992). Biological nitrogen fixation: Investments, expectations and actual contributions to agriculture. Plant and Soil, 141(1), 13-39. https://doi.org/10.1007/BF00011308

Pizzeghello, D., Francioso, O., Ertani, A., Muscolo, A., \& Nardi, S. (2013). Isopentenyladenosine and cytokinin-like activity of different humic substances. Journal of Geochemical Exploration, 129, $70-75$. https://doi.org/10.1016/j.gexplo.2012.10.007

Prado, M. R. V., Weber, O. L. D. S., Moraes, M. F. D., Santos, C. L. R. D., Santos Tunes, M., \& Ramos, F. T. (2016). Humic Substances on Soybeans Grown Under Water Stress. Communications in Soil Science and Plant Analysis, 47(21), 2405-2413. https://doi.org/10.1080/00103624.2016.1243715

Puglisi, E., Fragoulis, G., Ricciuti, P., Cappa, F., Spaccini, R., Piccolo, A., Trevisan, M., \& Crecchio, C. (2009). Effects of a humic acid and its size-fraction on the bacterial community of soil rhizosphere under maize (Zea mays L.). Chemosphere, 77(6), 829-837. https://doi.org/10.1016/j.chemosphere.2009.07.077

Rodríguez, H., \& Fraga, R. (1999). Phosphate solubilizing bacteria and their role in plant growth promotion. Biotechnology Advances, 17(4), 319-339. https://doi.org/10.1016/S0734-9750(99)00014-2

Sanjari, M. M., Sirousmehr, A., \& Fakheri, B. (2015). The effects of drought stress and humic acid on some physiological characteristics of roselle (Hibiscus sabdariffa). Journal of Crops Improvement, 17, $403-414$.

Selim, E., Shedeed, S. I., Asaad, F. F., \& El-Neklawy, A. S. (2012). Interactive effects of humic acid and water stress on chlorophyll and mineral nutrient contents of potato plants (Vol. 8).

Shand, C. (2007). Plant nutrition for food security. A guide for Integrated Nutrient Management (p. 348).

Sharma, D. K., Andersen, S. B., Ottosen, C. O., \& Rosenqvist, E. (2015). Wheat cultivars selected for high Fv/Fm under heat stress maintain high photosynthesis, total chlorophyll, stomatal conductance, transpiration and dry matter. Physiologia Plantarum, 153(2), 284-298. https://doi.org/10.1111/ppl.12245

Shool, A., \& Shamshiri, M. H. (2014). Effect of arbuscular mycorrhizal fungi and Pseudomonas fluorescence on chlorophyll fluorescence and photosynthetic pigments of pistachio seedlings (Pistaciavera cv. Qazvini) under four water regimes. Eur. J. Exp. Biol., 4, 246-252.

Siddiqui, Y., Islam, T. M., Naidu, Y., \& Meon, S. (2011). The conjunctive use of compost tea and inorganic fertiliser on the growth, yield and terpenoid content of Centella asiatica (L.) urban. Scientia Horticulturae, 130(1), 289-295. https://doi.org/10.1016/j.scienta.2011.05.043

Singh, R. R., \& Prasad, K. (2011). Effect of bio-fertilizers on growth and productivity of wheat (Triticum aestivum). J. Farm Sci., 1(1), 1-8.

Somers, E., Vanderleyden, J., \& Srinivasan, M. (2004). Rhizosphere Bacterial Signalling: A Love Parade Beneath Our Feet. Critical Reviews in Microbiology, 30(4), 205-240. https://doi.org/10.1080/1040841049 0468786

Spaccini, R., Piccolo, A., Conte, P., Haberhauer, G., \& Gerzabek, M. H. (2002). Increased soil organic carbon sequestration through hydrophobic protection by humic substances. Soil Biology and Biochemistry, 34(12), 1839-1851. https://doi.org/10.1016/S0038-0717(02)00197-9

Sundara, B., Natarajan, V., \& Hari, K. (2002). Influence of phosphorus solubilizing bacteria on the changes in soil available phosphorus and sugarcane and sugar yields. Field Crops Research, 77(1), 43-49. https://doi.org/10.1016/S0378-4290(02)00048-5

Swaina, A., Bastiraya, A., Jitendraa, K., \& Haibrub, R. (2014). Estimation of soil microbial biomass using substrate induced respiration: An experimental review study with loamy soil of north bangalore.

Tahiri, A., Destain, J., Thonart, P., \& Druart, P. (2015). In vitro model to study the biological properties of humic fractions from landfill leachate and leonardite during root elongation of Alnus glutinosa L. Gaertn and Betula pendula Roth. Plant Cell, Tissue and Organ Culture (PCTOC), 122(3), 739-749. https://doi.org/10.1007/s11240-015-0807-2 
Taïbi, K., Taïbi, F., Abderrahim, L. A., Ennajah, A., Belkhodja, M., \& Mulet, J. M. (2016). Effect of salt stress on growth, chlorophyll content, lipid peroxidation and antioxidant defence systems in Phaseolus vulgaris L. South African Journal of Botany, 105, 306-312. https://doi.org/10.1016/j.sajb.2016.03.011

Turan, M., Ekinci, M., Yildirim, E., Güneş, A., Karagöz, K., Kotan, R., \& Dursun, A. (2014). Plant growth-promoting rhizobacteria improved growth, nutrient, and hormone content of cabbage (Brassica oleracea) seedlings. Turkish Journal of Agriculture and Forestry, 38(3), 327-333. https://doi.org/10.3906/ tar-1308-62

Vallini, G., Pera, A., Avio, L., Valdrighi, M., \& Giovannetti, M. (1993). Influence of humic acids on laurel growth, associated rhizospheric microorganisms, and mycorrhizal fungi. Biology and Fertility of Soils, 16(1), 1-4. https://doi.org/10.1007/BF00336506

Vaneeckhaute, C., Meers, E., Michels, E., Ghekiere, G., Accoe, F., \& Tack, F. (2013). Closing the nutrient cycle by using bio-digestion waste derivatives as synthetic fertilizer substitutes: A field experiment. Biomass and Bioenergy, 55, 175-189. https://doi.org/10.1016/j.biombioe.2013.01.032

Vaughan, D., \& MacDonald, I. (1976). Some effects of humic acid on cation uptake by parenchyma tissue. Soil Biology and Biochemistry, 8(5), 415-421. https://doi.org/10.1016/0038-0717(76)90043-2

Vaughan, D., \& Malcolm, R. (1985). Influence of humic substances on growth and physiological processes. Soil organic matter and biological activity (pp. 37-75). Springer. https://doi.org/10.1007/978-94-009-5105-1_2

Visser, S. A. (1985). Effect of humic acids on numbers and activities of micro-organisms within physiological groups. Organic Geochemistry, 8(1), 81-85. https://doi.org/10.1016/0146-6380(85)90055-5

Yildirim, E. (2007). Foliar and soil fertilization of humic acid affect productivity and quality of tomato. Acta Agriculturae Scandinavica, Section B-Soil \& Plant Science, 57(2), 182-186. https://doi.org/10.1080/ 09064710600813107

Young, C., \& Chen, L. (1997). Polyamines in humic acid and their effect on radical growth of lettuce seedlings. Plant and Soil, 195(1), 143-149. https://doi.org/10.1023/A:1004247302388

Yuwono, T., Handayani, D., \& Soedarsono, J. (2005). The role of osmotolerant rhizobacteria in rice growth under different drought conditions. Australian Journal of Agricultural Research, 56(7), 715-721. https://doi.org/10.1071/AR04082

Zhang, C., \& Kong, F. (2014). Isolation and identification of potassium-solubilizing bacteria from tobacco rhizospheric soil and their effect on tobacco plants. Applied Soil Ecology, 82, 18-25. https://doi.org/ 10.1016/j.apsoil.2014.05.002

Zhang, H., Tan, S., Wong, W., Ng, C., Teo, C., Ge, L., ... Yong, J. (2014). Mass spectrometric evidence for the occurrence of plant growth promoting cytokinins in vermicompost tea. Biology and Fertility of Soils, 50(2), 401-403. https://doi.org/10.1007/s00374-013-0846-y

Zhang, X., \& Ervin, E. J. C. S. (2004). Cytokinin-containing seaweed and humic acid extracts associated with creeping bentgrass leaf cytokinins and drought resistance. Crop Science, 44(5), 1737-1745. https://doi.org/ $10.2135 /$ cropsci2004.1737

Zhang, Y., Xie, Z., Wang, Y., Su, P., An, L., \& Gao, H. (2011). Effect of water stress on leaf photosynthesis, chlorophyll content, and growth of oriental lily. Russian Journal of Plant Physiology, 58(5), 844. https://doi.org/10.1134/S1021443711050268

Zhu, J., Tremblay, N., \& Liang, Y. (2012). Comparing SPAD and atLEAF values for chlorophyll assessment in crop species. Canadian Journal of Soil Science, 92(4), 645-648. https://doi.org/10.4141/cjss2011-100

Zhu, Y.-G., Cavagnaro, T. R., Smith, S. E., \& Dickson, S. (2001). Backseat driving? Accessing phosphate beyond the rhizosphere-depletion zone. Trends in Plant Science, 6(5), 194-195. https://doi.org/ $10.1016 /$ S1360-1385(01)01957-4

\section{Copyrights}

Copyright for this article is retained by the author(s), with first publication rights granted to the journal.

This is an open-access article distributed under the terms and conditions of the Creative Commons Attribution license (http://creativecommons.org/licenses/by/4.0/). 